\title{
Pengaruh Kuat Arus Dan Besar Sudut Kampuh Terhadap Kekuatan Impact Dan Nilai Kekerasan Plat Baja Karbon Rendah Dengan Menggunakan Las SMAW
}

\author{
Soleh Abdul Aziz ${ }^{1}$, Abdul Qolik ${ }^{2}$, Duwi Leksono Edy ${ }^{3}$ \\ 1,2,3 Jurusan Teknik Mesin Fakultas Teknik Universitas Negeri Malang \\ e-mail:1Solehabdulaziz.02@gmail.com,
}

\begin{abstract}
Abstrak: Pengelasan adalah penyambungan logam yang memanfaatkan panas nyala pada busur listrik untuk mencairkan elektroda dan benda kerja. Pengelasan SMAW ini banyak digunakan karena penggunaanya yang relatif mudah, ramah biaya dan kualitas hasil yang maksimal. Dalam melakukan pengelasan memiliki beberapa faktor yang akan mempengaruhi dari kualitas hasil pengelasan seperti juru las, arus las dan jarak logam serta sudut kampuh pengelasan. Penelitian ini bertujuan untuk mengetahui apakah ada pengaruh variasi arus dan besar sudut kampuh terhadap nilai kekuatan impact dan nilai kekerasan hasil pengelasan SMAW. Penelitian ini menggunakan metode pre-eksperimental dengan model one-shot case. Hasil penelitian ini menunjukan nilai kekuatan impact tertinggi variasi arus pada kelompok spesimen 80 Ampere sudut kampuh $\mathrm{V} 60^{\circ}$ yaitu sebesar $0,0799 \mathrm{~J} / \mathrm{mm}^{2}$ dan pada spesimen 80 Ampere sudut kampuh $\mathrm{V} 80^{\circ}$ yaitu sebesar $0,0942 \mathrm{~J} / \mathrm{mm}^{2}$. Kemudian untuk nilai kekuatan impact tertinggi variasi sudut kampuh V kelompok spesimen sudut kampuh $\mathrm{V} 80^{\circ}$ arus 80 Ampere yaitu sebesar $0,0942 \mathrm{~J} / \mathrm{mm}^{2}$ dan spesimen sudut kampuh V $80^{\circ}$ arus 100 Ampere $0.0824 \mathrm{~J} / \mathrm{mm}^{2}$. Nilai kekerasan tertinggi didapatkan dengan variasi arus kelompok spesimen 100 Ampere sudut kampuh V $60^{\circ}$ yaitu sebesar 187,1 HVN dan pada kelompok spesimen 100 Ampere dengan sudut kampuh V 80 ${ }^{\circ}$ yaitu sebesar 204.4 HVN. Kemudian nilai kekerasan tertinggi variasi sudut kampuh V spesimen V $80^{\circ}$ dengan arus 80 Ampere yaitu sebesar 191.63 HVN dan spesimen sudut kampuh V $80^{\circ}$ dengan arus 100 ampere yaitu sebesar 204.4 HVN.
\end{abstract}

Kata kunci: SMAW, Arus, Kampuh V, Kekuatan Impact, Kekerasan

\begin{abstract}
Welding is welding that utilizes flame heat in electric arcs to melt electrodes and workpieces. SMAW welding is widely used because of its relatively easy to use, cost-friendly and maximum quality results. In conducting welding has several factors that will affect the quality of the welding results such as a welder, welding current and metal distance and welding seam angle. This study aims to determine whether there is an influence of current variations and magnitude of the seam angle to the value of the impact strength and the hardness value of the SMAW welding results. This study uses a pre-experimental method with a one-shot case model. The results of this study indicate the highest impact strength values of current variations in the 80 Ampere specimen at the angle of seam $\mathrm{V} 60^{\circ}$ in the amount of $0.0799 \mathrm{~J} / \mathrm{mm}^{2}$ and in the 80 Ampere specimen in the angle of the $80^{\circ} \mathrm{V}$ in the seam angle of $0.0942 \mathrm{~J} / \mathrm{mm}^{2}$. Then for the highest impact strength value variation of seam angle $\mathrm{V}$ group of seam angle specimen $\mathrm{V} 80^{\circ}$ current 80 Amperes is equal to $0.0942 \mathrm{~J} / \mathrm{mm}^{2}$ and specimen angle of seam V $80^{\circ}$ current 100 Ampere $0.0824 \mathrm{~J} / \mathrm{mm}^{2}$. The highest hardness value is obtained with a variation of the current specimen group of 100 Ampere in the angle of seam $\mathrm{V} 60^{\circ}$ that is equal to 187.1 HVN and in the specimen group 100 Ampere with the angle of contact V 80o that is equal to 204.4 HVN. Then the highest hardness value variation angle seam V specimen V $80^{\circ}$ with current 80 Amperes is equal to 191.63 $\mathrm{HVN}$ and specimen angle of seam V $80^{\circ}$ with 100 amperes current that is equal to $204.4 \mathrm{HVN}$.
\end{abstract}

KeyWords : SMAW, Welding current, V groove, Impact Strength, Hardness 
Proses penyambungan ialah metode yang perlu disorot atau di awasi dalam bidang perakitan yaitu dalam bidang mesin konstruksi dan konstruksi baja. Banyak macam teknik penyambungan yang dapat digunakan, salah satunya yaitu adalah teknik sambungan dengan pengelasan. Pada masa sekarang ini pembangunan konstruksi yang berbahan logam menyeret banyak proses penyambungan terkhusus pada bidang rancang bangun. Teknik pengelasan ini banyak digunakan dalam bidang konstruksi misalnya seperti perkapalan, sambungan pipa, sarana transportasi dan lain-lain. Pengelasan merupakan model atau metode penyambungan dua buah logam maupun logam paduan yang dicairkan atau lumer dan logam pengisi dengan atau tanpa adanya tambahan logam sehingga menghasilkan sambungan kontinyu.

"Shielded Metal Arc Welding (SMAW) adalah metode pengelasan yang memanfaatkan nyala busur sebagai pencair logam "Jalil \& Rahayu, (2017:58). Metode pengelasan SMAW adalah proses pengelasan manual yang mengguakan tangan dan sangat mudah. Metode las SMAW ini dapat dipakai mengelas semua bahan bangunan metal atau logam baik tipis maupun tebal. Mawahib, dkk, (2017:27) . Pengelasan SMAW banyak digunakan dikarenakan metodenya mudah dan ramah biaya. Namun kualitas hasil pengelasan ini tergantung dari beberapa faktor seperti juru las, variasi arus, jarak logam dan kampuh pengelasan. Arus las merupakan parameter las yang langsung terlibat dalam kecepatan pencairan logam induk dan penembusan, makin tinggi arus las maka makin besar penembusan dan kecepatan pencairannya. Setiap jenis elektroda dan besar diameter elektroda yang digunakan berbeda-beda pula arus yang di anjurkan dalam proses pengelasannya. Penggunaan arus yang di anjurkan bisa dilihat pada setiap elektroda yang digunakan, bila penggunaan arus yang telah dianjurkan tidak diterapkan dalam proses pengelasan, maka akan mengakibatkan hasil dari pengelasan itu tidak maksimal yang akan mempengaruhi dari ketangguhan maupun dari kekerasannya.

Selain arus pengelasan yang mempengaruhi dari hasil kualitas pengelasan, penggunaan kampuh serta sambungan pengelasan juga harus diperhatikan dalam proses pengelasan, yang mana sebagai gambaran apabila suatu benda kerja baja karbon rendah yang akan dilas memiliki jarak satu sama lain akan tetapi dalam proses pengelasannya tidak menggunakan kampuh, maka hasil dari pengelasan tersebut kurang maksimal. Penggunaan kampuh juga harus disesuaikan dengan tebal benda kerja yang akan dilas, tebal benda kerja 6-12 mm di anjurkan menggunakan kampuh $\mathrm{V}$ dengan sudut kampuh berkisar 60 o sampai 900 .

Penggunaan model kampuh dan juga arus pengelasan yang kurang tepat pada sebuah pengelasan merupakan penyebab tidak maksimalnya hasil dari pengelasan, ini dipengaruhi oleh tegangan sisa akibat dari masukan panas pada proses pengelasan, selain itu penggunaan kampuh las yang tidak tepat juga menyebabkan kegagalan dari sambungan las. Pemilihan kampuh yang sesuai dengan pembebanannyan akan mempengaruhi sifat mekanik dan fisis seperti ketangguahan serta kekerasan dari hasil pengelasan tersebut. Penggunaan kampuh yang baik dan sesuai dengan prosedur pengelasan dapat memberikan pengaruh dari hasil lasan atau sifat mampu las (Weld Ability) sehingga dapat meningkatkan ketangguhan. Pada pengelasan ada tiga daerah yang mengalami pemanasan daerah las , HAZ, dan logam induk. Daerah las adalah daerah yang mengalami deformasi plastis dan pemanasan selama proses pengelasan. Untuk mengetahui tingkat ketangguhan serta tingkat kekerasannya dilakukan sebuah pengujian, yaitu pengujian impact dan pengujian kekerasan yang mana pengujian impact merupakan yang mana uji impact merupakan alat yang digunakan untuk mengukur kemampuan beban kejut sebuah material kemudian uji kekerasan merupakan alat uji yang digunakan untuk mengetahui angka kekersan dari hasil pengelasan itu sendiri.

\section{METODE}

Berdasarkan tujuan penelitian yaitu untuk mengetahui nilai impact dan nilai kekerasan dengan variasi arus dan sudut kampuh pada sambungan las SMAW maka penelitian ini berbentuk angka-angka. Oleh karena itu penelitian ini adalah pendekatan kuantitatif. Creswell (2016:5) menyatakan bawha penelitian kuantitatif merupakan sebuah penelitian yang bertujuan membuktikan teori-teori dengan cara meneliti hubungan antara variabel yang diukur dengan instrument penelitian sehingga data hasil penelitian berbentuk angka-angka yang dapat dianalisis sesuai dengan prosedur statistik. Adapun jenis penelitian ini menggunkaan pendekatan eksperimental yaitu penelitian yang menentukan apakah sebuah threathment mempengaruhi sebuah penelitian Creswell (2016:17). Adapun penelitian dilakukan di laboraturium Sugiyono (2015:72). Desain penelitian ini menggunakan pre-eksperimental dengan model one-shot case studi dimana hasil penelitian ini tidak hanya dipengaruhi oleh variabel bebas. Pada penelitian ini dilakukan dibeberapa laboraturium antara lain : (1) Laboraturiom Pengujian logam Jurusan Teknik Universitas Negeri Malang.

Wartawan dalam hardiansyah (2018) menyatakan bahwa beberapa sifat dalam statistik adalah (1) stastistik adalah kumpulan fakta, jadi hanya satu data observasi belum cukup untuk membentuk statistik (2) pengambilan data minimal dilakukan 3 kali dalam satu variabel untuk membentuk statitik. 


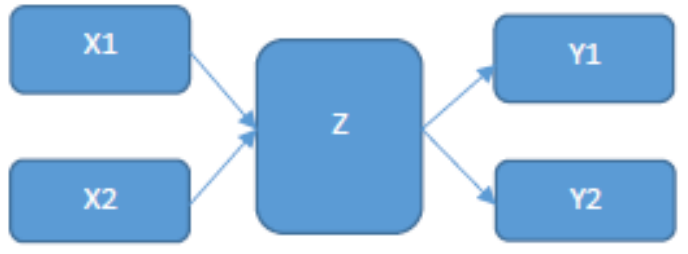

Gambar 1. Desain Penelitian

Keterangan:

Sumber: Kuntjojo (2009:39)

$\begin{array}{ll}\mathrm{X} 1 & \text { : Arus Pengelasan } \\ \mathrm{X} 2 & \text { : Sudut kampuh } \\ \mathrm{Y} 1 & \text { : Kekuatan Impact } \\ \mathrm{Y} 2 & \text { : Nilai Kekerasan } \\ \mathrm{Z} & \text { : Posisi Pengelasan }\end{array}$

Dimana adakah pengaruh arus pengelasan (X1) dan sudut kampuh (X2) terhadapan nilai kekuatan impact (Y1) sedangkan kemudian adakah pengaruh arus pengelasan (X1) dan sudut kampuh (X2) dan nilai kekerasan (Y2) yang mana nilai kekuatan impact (Y1) dan nilai kekerasan (Y2) juga bisa di pengaruhi oleh variable control yaitu posisi pengelasan (Z).

Dalam penelitian ini menggunakan baja karbon rendah ASTM A36 dengan ukuran berdasarkan Standart ASTM (American Standart Testing and Material) e23-16b dimana standart ini mengatur tentang test pieces for tensile test for metallic materials. Objek penelitian ini menggunakan kampuh V dengan sudut 60o dan 80o dengan jarak root face $1 \mathrm{~mm}$.

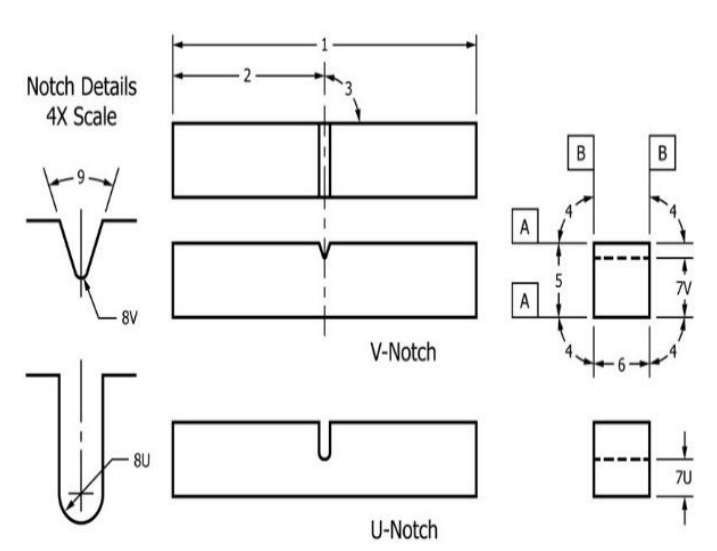

\begin{tabular}{|c|l|l|l|}
\hline Number & Description & Dimension & Tolerance \\
\hline 1 & Length of specimen & $55 \mathrm{~mm}$ & $\begin{array}{l}+0 /-2.5 \\
\mathrm{~mm}\end{array}$ \\
\hline 2 & Centering of notch & & $\pm 1 \mathrm{~mm}$ \\
\hline 3 & Notch length to edge & $90^{\circ}$ & $\pm 2^{\circ}$ \\
\hline 4 & Adjacent sides angle & $90^{\circ}$ & $\pm 0.17^{\circ}$ \\
\hline 5 & Width & $10 \mathrm{~mm}$ & $\pm 0.075 \mathrm{~mm}$ \\
\hline 6 & Thickness & $10 \mathrm{~mm}$ & $\pm 0.075 \mathrm{~mm}$ \\
\hline $7 \mathrm{~V}$ & Ligament length, Type V & $8 \mathrm{~mm}$ & $\pm 0.025 \mathrm{~mm}$ \\
\hline $7 \mathrm{U}$ & Ligament length, Type U & $5 \mathrm{~mm}$ & $\pm 0.075 \mathrm{~mm}$ \\
\hline $8 \mathrm{~V}$ & Radius of notch, Type V & $0.25 \mathrm{~mm}$ & $\pm 0.025 \mathrm{~mm}$ \\
\hline $8 \mathrm{U}$ & Radius of notch, Type U & $1 \mathrm{~mm}$ & $\pm 0.025 \mathrm{~mm}$ \\
\hline 9 & Angle of notch & $45^{\circ}$ & $\pm 1^{\circ}$ \\
\hline A & $\begin{array}{l}\text { Surface finish } \\
\text { requirements }\end{array}$ & $2 \mu \mathrm{m}(\mathrm{Ra})$ & $\#$ \\
\hline B & $\begin{array}{l}\text { Surface finish } \\
\text { requirements }\end{array}$ & $4 \mu \mathrm{m}(\mathrm{Ra})$ & $\#$ \\
\hline
\end{tabular}

Gambar 2. Ukuran Standart Penelitian ASTM

Sumber: ASTM (2016:2)

\section{HASIL}

Pengujian Kekerasan Vickers dilakukan di Laboratorium Pengujian Logam (Uji Kekerasan) Jurusan Teknik Mesin Universitas Negeri Malang. Metode uji kekerasan Vickers digunakan karena pada uji Vickers terdapat indentor yang ada pada uji Vickers dapat menguji material lunak maupun keras. Pengujian kekerasan dilakukan 6 titik pada setiap sampelnya, berarti terdapat 2 titik uji kekerasan di setiap spesimen uji. Gaya yang diberikan pada pengujian ini sebesar 500 gram force dengan 
waktu penahanan 10 detik. Adapun hasil pengujian kekerasan Vickers pada sambungan las menggunakan variasi arus dan sudut kampuh adalah sebagai berikut:

\section{Uji Vickers Pada Sudut Kampuh $60^{\circ}$ dengan Arus 80 A}

Berikut data hasil pengujian Vickers dengan variasi sudut kampu $60^{\circ}$ dengan arus $80 \mathrm{~A}$

Tabel 1. Data Hasil Uji Vickers Variasi Sudut Kampu $60^{\circ}$ dengan Arus 80 A

\begin{tabular}{|c|c|l|}
\hline Spesimen & Bagian & \multicolumn{1}{|c|}{ Nilai Kekerasan } \\
\hline Variasi Sudut Kampuh & Las & 1. 182.9 HVN \\
$60^{\circ}$ dengan Arus 80 A & & 2. 189.9 HVN \\
& & 3. 188.5 HVN \\
& & Rata-rata $=187.1 \mathrm{HVN}$ \\
\hline
\end{tabular}

Berdasarkan tabel 1 dapat dilihat hasil pengujian kekerasan vickers dengan variasi sudut kampu $60^{\circ}$ dengan arus 80 A didapat nilai kekerasan tertinggi pada daerah las yaitu 189,9 HVN sedangkan untuk nilai kekerasan terendah pada daerah las yaitu 182.9 HVN. Dari tiga titik uji pada daerah las didapat rata-rata untuk pada daerah las didapat 187.1 HVN yang sudah mengalami proses pengelasan dengan variasi sudut kampu $60^{\circ}$ dengan arus $80 \mathrm{~A}$.

\section{Uji Vickers Pada Sudut Kampuh $60^{\circ}$ dengan Arus 100 A}

Berikut data hasil pengujian vickers dengan variasi sudut kampu $60^{\circ}$ dengan arus 100 A yang dijabarkan pada table 2 .

Tabel 2. Data Hasil Uji Vickers Variasi Sudut Kampu $60^{\circ}$ dengan Arus 100 A

\begin{tabular}{|c|c|l|}
\hline Spesimen & Bagian & \multicolumn{1}{|c|}{ Nilai Kekerasan } \\
\hline Variasi Sudut & Las & 1. $185.1 \mathrm{HVN}$ \\
Kampuh $60^{\circ}$ dengan & & 2. $201.7 \mathrm{HVN}$ \\
Arus $100 \mathrm{~A}$ & & 3. $190.8 \mathrm{HVN}$ \\
& & Rata-rata $=192.53 \mathrm{HVN}$ \\
\hline
\end{tabular}

Berdasarkan tabel 2 dapat dilihat hasil pengujian kekerasan vickers dengan variasi sudut kampu $60^{\circ}$ dengan arus 100 A didapat nilai kekerasan tertinggi pada daerah las yaitu 201.7 HVN sedangkan untuk nilai kekerasan terendah pada daerah las yaitu 185.1 HVN. Dari tiga titik uji pada daerah las didapat rata-rata untuk pada daerah las didapat 190.53 HVN yang sudah mengalami proses pengelasan dengan variasi sudut kampu $60^{\circ}$ dengan arus $100 \mathrm{~A}$.

\section{Uji Vickers Pada Sudut Kampuh $80^{\circ}$ dengan Arus 80 A}

Berikut data hasil pengujian vickers dengan variasi sudut kampu $80^{\circ}$ dengan arus $80 \mathrm{~A}$

Tabel 3. Data Hasil Uji Vickers Variasi Sudut Kampu $80^{\circ}$ dengan Arus 80 A

\begin{tabular}{|c|c|l|}
\hline Spesimen & Bagian & \multicolumn{1}{|c|}{ Nilai Kekerasan } \\
\hline Variasi Sucut & Las & 1. $196.7 \mathrm{HVN}$ \\
Kampuh $80^{\circ}$ & & 2. $193.1 \mathrm{HVN}$ \\
dengan Arus 80 A & & 3. $185.1 \mathrm{HVN}$ \\
& & Rata-rata $=191.63 \mathrm{HVN}$ \\
\hline
\end{tabular}

Berdasarkan tabel 3 dapat dilihat hasil pengujian kekerasan vickers dengan variasi sudut kampu $80^{\circ}$ dengan arus $80 \mathrm{~A}$ didapat nilai kekerasan tertinggi pada daerah las yaitu 196.7 HVN sedangkan untuk nilai kekerasan terendah pada daerah las yaitu 185.1 HVN. Dari tiga titik uji pada daerah las didapat rata-rata untuk pada daerah las didapat $191.63 \mathrm{HVN}$ yang sudah mengalami proses pengelasan dengan variasi sudut kampu $80^{\circ}$ dengan arus $80 \mathrm{~A}$. 


\section{Uji Vickers Pada Sudut Kampuh 80 dengan Arus 100 A}

Berikut data hasil pengujian vickers dengan variasi sudut kampu $80^{\circ}$ dengan arus $100 \mathrm{~A}$.

Tabel 4. Data Hasil Uji Vicker Variasi Sudut Kampu 80 dengan Arus 100 A

\begin{tabular}{|c|c|l|}
\hline Spesimen & Bagian & \multicolumn{1}{|c|}{ Nilai Kekerasan } \\
\hline Variasi Sudut Kampuh & Las & 1. $212.1 \mathrm{HVN}$ \\
$80^{\circ}$ dengan Arus 100 A & & 2. $199.1 \mathrm{HVN}$ \\
& & 3. $202 \mathrm{HVN}$ \\
& & Rata-rata $=204,4 \mathrm{HVN}$ \\
\hline
\end{tabular}

Berdasarkan tabel 4 dapat dilihat hasil pengujian kekerasan vickers dengan variasi sudut kampu $80^{\circ}$ dengan arus 100 A didapat nilai kekerasan tertinggi pada daerah las yaitu 202 HVN sedangkan untuk nilai kekerasan terendah pada daerah las yaitu 199.1 HVN. Dari tiga titik uji pada daerah las didapat rata-rata untuk pada daerah las didapat 204.4 HVN yang sudah mengalami proses pengelasan dengan variasi sudut kampu 80o dengan arus $100 \mathrm{~A}$.

Pengujian Impact dilakukan di Laboratorium Pengujian Material Fakultas Teknologi Industri Jurusan Teknik Mesin Institut Teknologi Nasional Malang. Metode uji Impact digunakan untuk menganalisis karakteristik bahan seperti kemampuan bahan terhadap benturan dan juga karakteristik keuletan bahan terhadap perubahan suhu. Adapun hasil pengujian Impact pada sambungan las menggunakan variasi arus dan sudut kampuh adalah sebagai berikut:

\section{Uji Impact Pada Sudut Kampuh $60^{\circ}$ dengan Arus 80 A}

Berikut data hasil pengujian Impact dengan variasi sudut kampu $60^{\circ}$ dengan arus $80 \mathrm{~A}$.

Tabel 5. Data Hasil Uji Impact Variasi Sudut Kampu $60^{\circ}$ dengan Arus 80 A

\begin{tabular}{|c|c|}
\hline Spesimen & Nilai Impact \\
\hline variasi sudut kampuh & $1.0,0799 \mathrm{~J} / \mathrm{mm}$ \\
$60^{\circ}$ dengan arus $80 \mathrm{~A}$ & $2.0,0773 \mathrm{~J} / \mathrm{mm}$ \\
& $3.0,0826 \mathrm{~J} / \mathrm{mm}$ \\
& Rata-rata $=0,0799 \mathrm{~J} / \mathrm{mm}$ \\
\hline
\end{tabular}

Berdasarkan tabel 5 dapat dilihat hasil pengujian Impact dengan variasi sudut kampu $60^{\circ}$ dengan arus 80 A didapat nilai Kekuatan Impact tertinggi yaitu 0,0826 J/mm sedangkan untuk nilai Impact terendah yaitu 0,0773 J/mm Dari tiga uji pada spesimen didapat rata-rata $0,0799 \mathrm{~J} / \mathrm{mm}$ yang sudah mengalami proses pengelasan dengan variasi sudut kampu $60^{\circ}$ dengan arus $80 \mathrm{~A}$.

\section{Uji Impact Pada Sudut Kampuh 60 $0^{\circ}$ engan Arus 100 A}

Berikut data hasil pengujian Impact dengan variasi sudut kampu $60^{\circ}$ dengan arus $100 \mathrm{~A}$.

Tabel 6. Data Hasil Uji Impact Variasi Sudut Kampu $60^{\circ}$ dengan Arus 100 A 


\begin{tabular}{|c|c|}
\hline Spesimen & Nilai Impact \\
\hline variasi sudut kampuh & $1.0,0747 \mathrm{~J} / \mathrm{mm}$ \\
$60^{\circ}$ dengan arus 100 & $2.0,0720 \mathrm{~J} / \mathrm{mm}$ \\
A & $3.0,0720 \mathrm{~J} / \mathrm{mm}$ \\
& Rata-rata $=0,0729 \mathrm{~J} / \mathrm{mm}$ \\
\hline
\end{tabular}

Berdasarkan tabel 6 dapat dilihat hasil pengujian Impact dengan variasi sudut kampu $60^{\circ}$ dengan arus 100 A didapat nilai Kekuatan Impact tertinggi yaitu $0,07247 \mathrm{~J} / \mathrm{mm}$ sedangkan untuk nilai Impact terendah yaitu 0,0720 J/mm Dari tiga uji pada spesimen didapat rata-rata $0,0799 \mathrm{~J} / \mathrm{mm}$ yang sudah mengalami proses pengelasan dengan variasi sudut kampu $60^{\circ}$ dengan arus $100 \mathrm{~A}$.

\section{Uji Impact Pada Sudut Kampuh $80^{\circ}$ dengan Arus 80 A}

Berikut data hasil pengujian impact dengan variasi sudut kampu $80^{\circ}$ dengan arus $80 \mathrm{~A}$.

Tabel 7. Data Hasil Uji Impact Variasi Sudut Kampu $80^{\circ}$ dengan Arus $80 \mathrm{~A}$

\begin{tabular}{|c|c|}
\hline Spesimen & Nilai Impact \\
\hline variasi sudut kampuh & $1.0,0952 \mathrm{~J} / \mathrm{mm}$ \\
$80^{\circ}$ dengan arus $80 \mathrm{~A}$ & $2.0,1025 \mathrm{~J} / \mathrm{mm}$ \\
& $3.0,0851 \mathrm{~J} / \mathrm{mm}$ \\
& Rata-rata $=0,0942 \mathrm{~J} / \mathrm{mm}$ \\
\hline
\end{tabular}

Berdasarkan tabel 7 dapat dilihat hasil pengujian Impact dengan variasi sudut kampu $60^{\circ}$ dengan arus 80 A didapat nilai Kekuatan Impact tertinggi yaitu 0,1025 J/mm sedangkan untuk nilai Impact terendah yaitu 0,0851 J/mm Dari tiga uji pada spesimen didapat rata-rata $0,0942 \mathrm{~J} / \mathrm{mm}$ yang sudah mengalami proses pengelasan dengan variasi sudut kampu $80^{\circ}$ dengan arus $80 \mathrm{~A}$.

\section{Uji Impact Pada Sudut Kampuh $80^{\circ}$ dengan Arus 100 A}

Berikut data hasil pengujian impact dengan variasi sudut kampu $80^{\circ}$ dengan arus $100 \mathrm{~A}$.

Tabel 8. Data Hasil Uji Impact Variasi Sudut Kampu 80 dengan Arus 100 A

\begin{tabular}{|c|c|}
\hline Spesimen & Nilai Impact \\
\hline variasi sudut kampuh & $1.0,0902 \mathrm{~J} / \mathrm{mm}$ \\
$80^{\circ}$ dengan arus 100 & $2.0,0720 \mathrm{~J} / \mathrm{mm}$ \\
A & $3.0,0851 \mathrm{~J} / \mathrm{mm}$ \\
& Rata-rata $=0,0824 \mathrm{~J} / \mathrm{mm}$ \\
\hline
\end{tabular}

Berdasarkan tabel 8 dapat dilihat hasil penggujian Impact dengan variasi sudut kampu 80o dengan arus 100 A didapat nilai Kekuatan Impact tertinggi yaitu 0,0902 J/mm sedangkan untuk nilai Impact terendah yaitu 0,0720 J/mm Dari tiga uji pada spesimen didapat rata-rata $0,0824 \mathrm{~J} / \mathrm{mm}$ yang sudah mengalami proses pengelasan dengan variasi sudut kampu $80^{\circ}$ dengan arus $100 \mathrm{~A}$.

\section{PEMBAHASAN}

Hasil penelitian menggunakan variasi sudut kampuh $\mathrm{V} 60^{\circ}$ dengan arus 80 A dan 100 A menunjukan hasil nilai kekerasan relatif tinggi yaitu ada pada variasi arus 100 A dengan sudut kampuh $60^{\circ}$. uji kekerasan dilakukan pada daerah las. Hal ini juga terjadi pada hasil penelitian tabel 3 dan tabel 4 hasil penelitian menggunakan variasi sudut kampuh $\mathrm{V} 80^{\circ}$ dengan 
arus 80 A dan 100 A menunjukan hasil nilai kekerasan yang relatif tinggi yaitu ada pada variasi arus 100 A dengan sudut kampuh $80^{\circ}$. Untuk hasil penelitian ini yang mana menggunakan variasi sudut kampuh $60^{\circ}$ dengan arus 80 A dan 100 A serta kemudian hasil penelitian dengan variasi sudut kampuh $80^{\circ}$ dengan arus $80 \mathrm{~A}$ dan $100 \mathrm{~A}$ bisa dilihat pada gambar 3 dan gambar 4 .

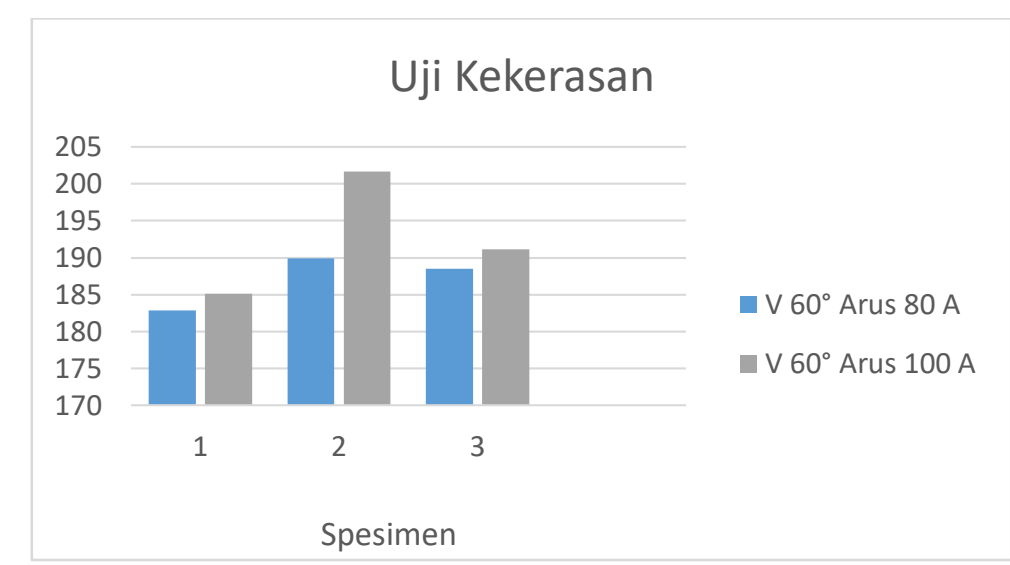

Gambar 3. Diagram Uji Kekerasan Sudut Kampuh V 60 dengan Arus 80 A dan Arus 100 A

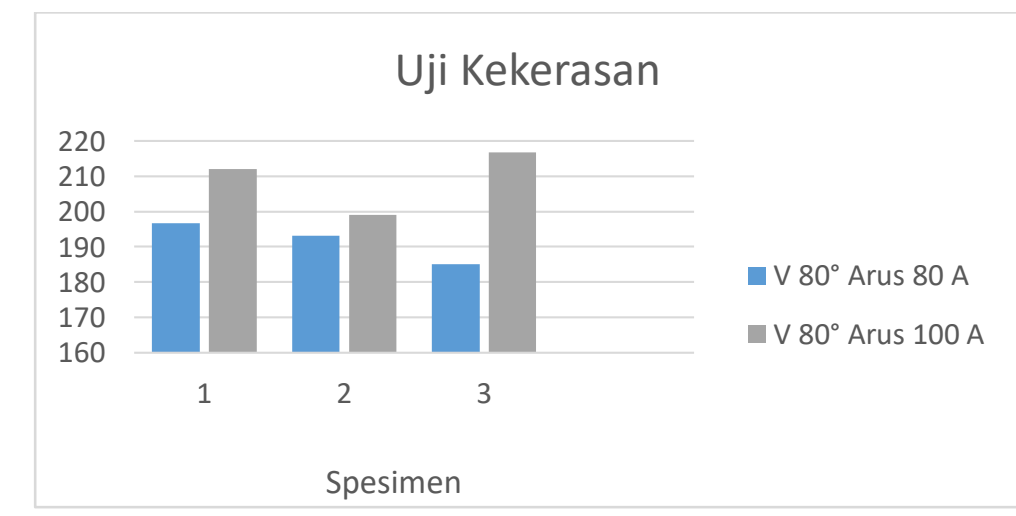

Gambar 4. Diagram Uji Kekerasan Sudut Kampuh V 80 dengan Arus 80 A dan Arus 100 A

Berdasarkan gambar 3 dan gambar 4 yang merupakan hasil dari penelitian ini menunjukan semakin tinggi arus pengelasan yang digunakan maka akan menyebabkan nilai kekerasan pada dearah las juga akan meningkat. Hal karena disebabkan bahwa peningkatan panas akan membuat struktur logamnya menjadi kasar dengan semakin tinggi temperatur arus las juga akan memperbesar butir. Nilai kekerasan dengan arus 100 Amper dengan sudut kampuh $\mathrm{V} 60^{\circ}$ maupun $80^{\circ}$ yang digunakan merupakan nilai kekerasan spesimen paling tinggi.

Untuk hasil penelitian pada tabel 1 dan 3 menggunakan variasi sudut kampuh $\mathrm{V}$ dengan sudut $60^{\circ}$ dan $80^{\circ}$ menggunakan arus 80 Ampere menunjukan hasil yang mana nilai kekerasan relatif tinggi yaitu ada sudut kampuh $\mathrm{V} 80^{\circ}$ dengan arus 80 ampere. uji kekerasan dilakukan pada daerah las. Hal ini juga terjadi pada hasil penelitian tabel 2 dan tabel 4 yang hasil penelitian menggunakan variasi sudut kampuh variasi sudut kampuh V dengan sudut $60^{\circ}$ dan $80^{\circ}$ dengan Arus 100 A menunjukan hasil nilai kekerasan yang relatif tinggi yaitu ada pada variasi arus 100 A dengan sudut kampuh 80o. Untuk hasil penelitian ini yang mana menggunakan variasi sudut kampuh $60^{\circ}$ dan $80^{\circ}$ A dengan arus 80 A serta kemudian hasil penelitian dengan variasi sudut kampuh $60^{\circ}$ dan $80^{\circ}$ A dengan arus 100 A bisa dilihat pada gambar 5 dan gambar 6. 


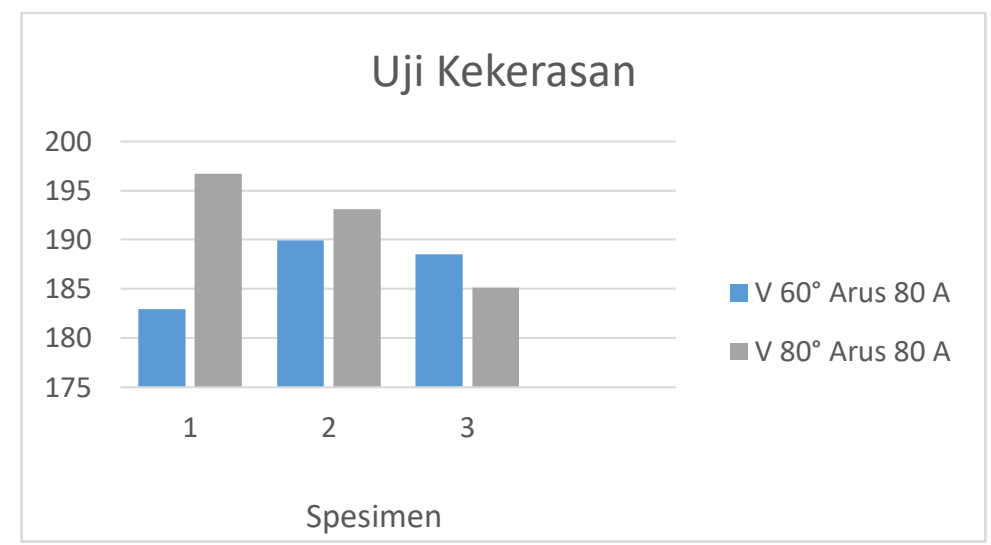

Gambar 5. Diagram Uji Kekerasan Sudut Kampuh V $60^{\circ}$ dan $80^{\circ}$ A dengan Arus 80 A

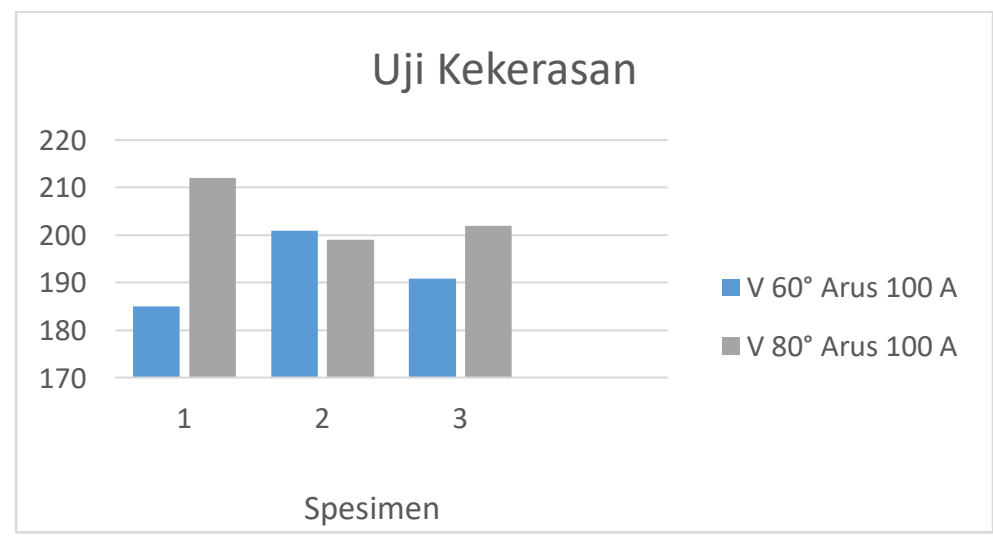

Gambar 6. Diagram Uji Kekerasan Sudut Kampuh V 60 dan $80^{\circ}$ A dengan Arus 100 A

Berdasarkan gambar 5 dan gambar 6 yang merupakan hasil dari penelitian ini menunjukan semakin besar sudut kampuh $\mathrm{V}$ yang digunakan maka akan menyebabkan nilai kekerasan pada dearah las juga akan meningkat karena sudut kampuh yang lebih besar mempengaruhi dari masukan material las yang lebih merata. Nilai kekerasan dengan arus 100 Amper dengan sudut kampuh V 80o dan V 80o dengan arus 80 Amper digunakan merupakan nilai kekerasan spesimen paling tinggi.

Untuk tabel 5 dan tabel 6 yang mana hasil penelitian menggunakan variasi sudut kampuh $\mathrm{V} 60^{\circ}$ dengan arus 80 A dan 100 A menunjukan hasil yang mana nilai kekuatan impact relatif tinggi yaitu ada pada variasi arus 80 A dengan sudut kampuh $60^{\circ}$. Hal ini juga terjadi pada hasil penelitian tabel 7 dan tabel 8 yang hasil penelitian menggunakan variasi sudut kampuh $\mathrm{V} 80^{\circ}$ dengan arus $80 \mathrm{~A}$ dan $100 \mathrm{~A}$ menunjukan hasil nilai impact yang relatif tinggi yaitu ada pada variasi arus $80 \mathrm{~A}$ dengan sudut kampuh $80^{\circ}$. Untuk hasil penelitian ini yang mana menggunakan variasi sudut kampuh $60^{\circ}$ dengan arus 80 A dan 100 A serta kemudian hasil penelitian dengan variasi sudut kampuh $80^{\circ}$ dengan arus $80 \mathrm{~A}$ dan $100 \mathrm{~A}$ bisa dilihat pada gambar dibawah ini. 


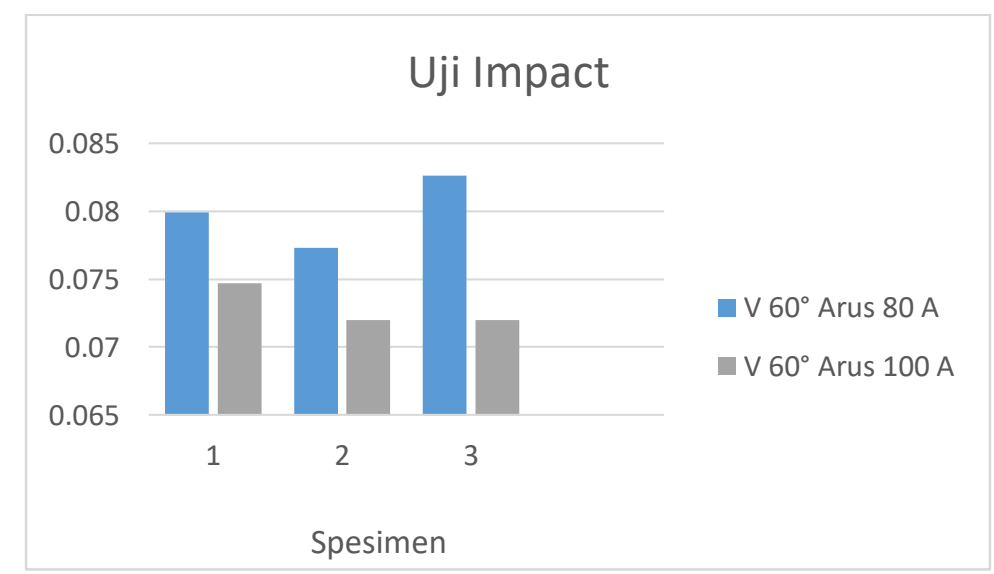

Gambar 7. Diagram Uji Impact Sudut Kampuh V 60 dengan Arus 80 A dan Arus 100 A

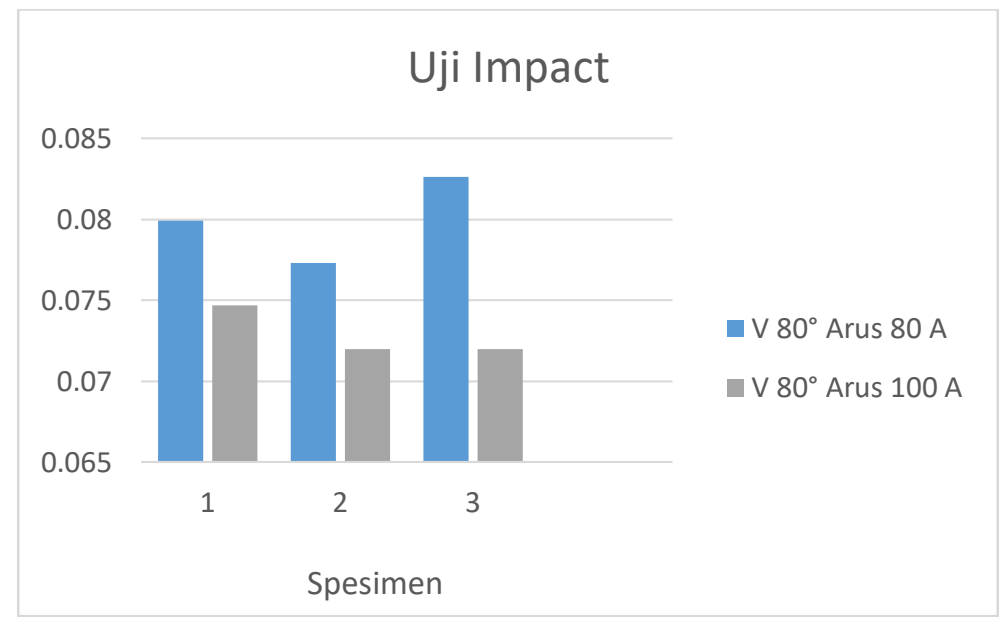

Gambar 8. Diagram Uji Impact sudut kampuh V 80 dengan Arus 80 A dan Arus 100 A

Berdasarkan gambar 7 dan gambar 8 yang merupakan hasil dari penelitian ini menunjukan semakin tinggi arus pengelasan yang digunakan maka akan menyebabkan nilai kekuatan impact akan menurun. Hal disebabkan karena masukan panas yang dihasilkan semakin berlebih sehingga kecenderungan memberikan peneterasi yang lebih menonjol dan terkadang karena masukan panas yang terlalu tinggi akan menyebabkan logam las menjadi getas. Nilai kekuatan impact dengan arus $80 \mathrm{~A}$ Amper dengan sudut kampuh $\mathrm{V} 60^{\circ}$ maupun $\mathrm{V} 80^{\circ}$ yang digunakan merupakan nilai kekuatan impact paling tinggi.

Untuk hasil penelitian pada tabel 5 dan 7 menggunakan variasi sudut kampuh $\mathrm{V}$ dengan sudut $60^{\circ}$ dan $80^{\circ}$ menggunakan arus 80 Ampere menunjukan hasil yang mana nilai kekuatan impact relatif tinggi pada kampuh $\mathrm{V} 80^{\circ}$ dengan Arus 80 Ampere. Hal juga terjadi pada penelitian tabel 6 dan tabel 8 yang hasil penelitian menggunakan variasi sudut kampuh variasi sudut kampuh $\mathrm{V}$ dengan sudut $60^{\circ}$ dan $80^{\circ}$ dengan Arus 100 A menunjukan hasil nilai kekuatan impact yang relatif tinggi yaitu ada pada variasi arus 100 A dengan sudut kampuh 80o. Untuk hasil penelitian ini yang mana menggunakan variasi sudut kampuh $60^{\circ}$ dan $80^{\circ}$ A dengan arus 80 A serta kemudian hasil penelitian dengan variasi sudut kampuh $60^{\circ}$ dan $80^{\circ} \mathrm{A}$ dengan arus 100 A bisa dilihat pada gambar dibawah ini. 


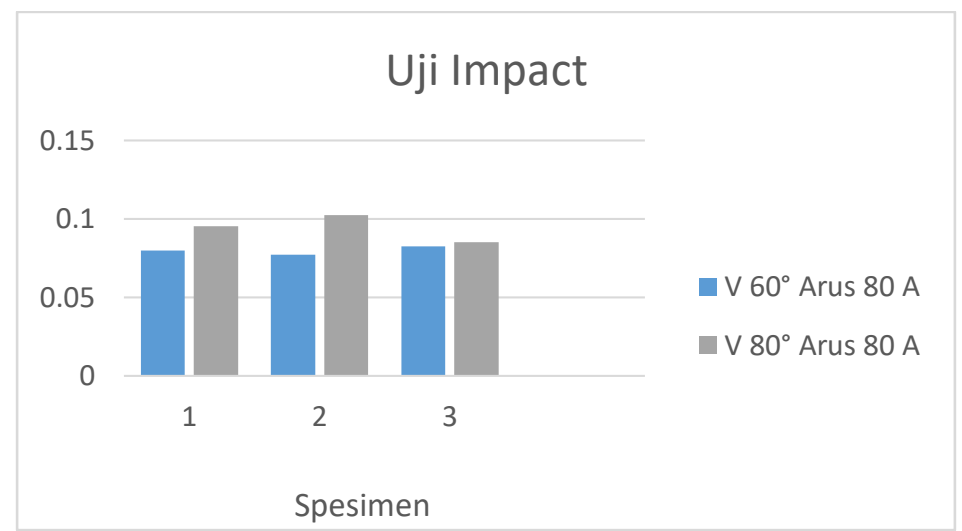

Gambar 9. Diagram Uji impact Sudut Kampuh V $60^{\circ}$ dan $80^{\circ}$ dengan Arus 80 A

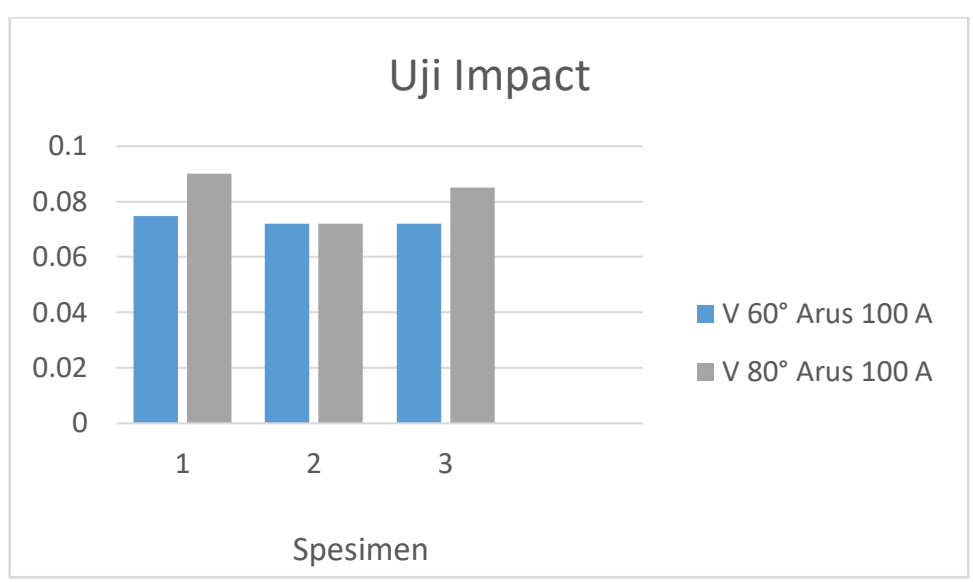

Gambar 10. Diagram Uji impact sudut kampuh V $60^{\circ}$ dan $80^{\circ}$ dengan Arus $100 \mathrm{~A}$

Berdasarkan gambar 9 dan gambar 10 yang merupakan hasil dari penelitian ini menunjukan semakin kecil sudut kampuh $\mathrm{V}$ yang digunakan maka akan menyebabkan nilai kekuatan impact akan menurun. Hal ini karena sudut kampuh 80o mempunyai permukaan yang lebih besar dibandingkan dengan permukaan sudut kampuh $60^{\circ}$. Hal ini disebabkan sudut kampuh yang lebih besar mempengaruhi dari masukan material las yang lebih merata dan kuat arus yang rendah mengurangi terjadinya lubang halus yang terjadi pada proses pengelasan sehingga dapat menigkatkan nilai kekuatan impact.. Nilai kekuatan impact dengan sudut kampuh $\mathrm{V} 80^{\circ}$ yang digunakan merupakan nilai kekuatan impact paling tinggi.

Berdasarkan hasil penelitian ini. Variasi arus dan variasi kampuh dapat mempengaruhi hasil nilai kekerasan dan nilai kekuatan impact. Hasil penenlitian ini menunjukan penggunaan arus yang besar pada proses pengelasan dapat meningkatkan nilai kekerasan akan tetapi menurunkan nilai kekuatan impact. Jika arus yang digunakan pada proses pengelasan menurun maka akan menurunkan nilai kekersan karena dan nilai kekutan impactnya naik. Ini dikarena sifat mekanis logam serta perubahan kerapatan mikro struktur yang disebabkan oleh laju pendinginan serta masukan panas yang merubah sifat dan kerapatan mikro strukturnya. Perubahan struktur mikro logam bergantung pada laju pendinginan suhu pengelasan dari suhu austenit sampai ke suhu kamar. laju pendinginan akan menentukan bentukan struktur mikro sambungan logam, pada laju pendinginan dari suhu austenit - ferit logam las yang berkomposisi karbon dan silicon dengan kadar komposisi $0.25-2.00 \%$ struktur mikro yang terbentuk akan lebih kasar dan berbentuk ferit+perlit yang memiliki sifat mekanis yang keras namun getas dan mudah patah.Hali ni dapat dibandingkan melalui tabel 1 dan 2 Untuk nilai kekerasan yang menggunakan variasi arus dan untuk membandingkan nilai kekuatan impactnya bisa dilihattpada tabel 5 dan tabel 6

Selanjutnya jika sudut kampuh V yang digunakan besar maka akan meningkatkan nilai kekerasan dan nilai kekuatan impactnya juga meningkat. Ini disebabkan masukan panas dan luas permukaan las dari proses pengelasan mengkibatkan struktur mikro perlit meningkat yang otomatis nilai kekerasan juga akan meningkat struktur perlit ini memiliki sifat yang cenderung kuat dan keras namun getas. Dengan hal tersebut maka dapat diartikan bahwa besar sudut kampuh $\mathrm{V}$ yang digunakan mempengaruhi hasil dari nilai kekerasan maupun nilai kekutan impact. .Hal ini dapat dibandingkan melalui tabel 1 dan 3 Untuk nilai kekerasan dan untuk membandingkan nilai kekuatan impactnya bisa dilihat pada tabel 5 dan tabel 7. 


\section{PENUTUP}

Berdasarkan datakhasil pengujian pada penelitian ini terhadap kekuatan impact dan nilai kekerasan plat baja karbon rendah dengan menggunakan las smaw dapat disimpulkan bahwa:

Variasi arus yang digunakan pengelasan SMAW pada plat baja karbon rendah ASTM A36 memberikan pengaruh terhadap nilai kekerasan. Nilai kekerasan akan semakin meningkat apabila arus yang digunakan besar hasil penelitian pada spesimen dengan Variasi sudut kampuh $60^{\circ}$ dengan arus 80 dan 100 A menghasilkan nilai kekerasan yang tinggi pada arus 100 A. sama halnya dengan hasil penelitian pada variasi sudut kampuh $80^{\circ}$ dengan arus 80 dan 100 A yang menghasilkan nilai kekerasan tertingga pada variasi arus 100 A yang digunakan.

Variasi sudut kampuh yang digunakan dalam proses pengelasan SMAW pada plat baja karbon rendah ASTM A36 memberikan pengaruh terhadapa nilai kekerasannya. Nilai kekerasan akan meningkat apabila sudut kampuh $\mathrm{V}$ yang digunakan besar. Hasil dari penelitian pada spesimen dengan variasi sudut kampuh $\mathrm{V} 60^{\circ}$ dan $80^{\circ}$ dengan Arus 80 menghasilkan nilai kekerasan tertinggi pada spesimen dengan variasi sudut kampuh $80^{\circ}$. sama halnya dengan hasil penelitian pada variasi sudut kampuh $60^{\circ}$ dan $80^{\circ}$ denganiarus 100 A menghasilkan nilai kekerasan tertinggi pada spesimen dengan sudut kampuh $80^{\circ}$

Variasi arus yang digunakan pengelasan SMAW pada plat baja karbon rendah ASTM A36 memberikan pengaruh terhadap nilai kekuatan impact. Nilai impact akan semakin meningkat apabila arus yang digunakan rendah. Hasil penelitian pada spesimen dengan variasi sudut kampuh $60^{\circ}$ dengan arus 80 dan 100 A menghasilkan nilai impact yang tinggi pada arus 80 A. sama halnya dengan hasil penelitian pada variasi sudut kampuh $80^{\circ}$ dengan arus 80 dan 100 A yang menghasilkan nilai impact tertingga pada variasi arus 80 A yang digunakan.

Variasi sudut kampuh yang digunakan dalam proses pengelasan SMAW pada plat baja karbon rendah ASTM A36 memberikan pengaruh terhadapa nilai kekuatan impactnya. Nilai kekuatan impactnya akan meningkat apabila sudut kampuh $\mathrm{V}$ yang digunakan besar. Hasil dari penelitian pada spesimen dengan variasi sudut kampuh $\mathrm{V} 60^{\circ}$ dan $80^{\circ}$ dengan arus 80 menghasilkan nilai kekuatan impact tertinggi pada spesimen dengan variasi sudut kampuh $80^{\circ}$. sama halnya dengan hasil penelitian pada variasi sudut kampuh $60^{\circ}$ dan $80^{\circ}$ dengan arus 100 A menghasilkan nilai kekuatan impact tertinggi pada spesimen dengan sudut kampuh 80.

\section{DAFTAR RUJUKAN}

ASTM International (E23-16b) Standard Test Methods for Notched Bar Impact Testing of Metallic Materials. 2016

Cresswell, John W. 2016. Research Desain: Pendekatan Metode Kualitatif, Kuantitatif, dan Campuran. Yogyakarta: Pustaka Pelajar

Groover, Mikell P. 2010. Fundamentals of Modern Manufacturing Fourth Edition. New Jersey: John Wiley \& Sons, Inc.

Hardiansyah, T. 2018. Pengaruh Variasi Kuat Arus dan Wire Feed Rate Pada Baja Karbon Rendah Terhadap Kekuatan Tarik Hasil Pengelasan GMAW. Skripsi Tidak Diterbitkan. Malang: Fakultas Teknik Universitas Negeri Malang

Huda, M., \& Setiawan, F. 2016. Pengaruh Variasi Sudut Kampuh V dan Kuat Arus dengan Las Shielded Metal Arc Welding (SMAW) pada Baja A36 Terhadap Sifat Mekanik. Jurnal Ilmiah Teknik Mesin, 1-9

Jalil, S. A., \& Rahayu, T. 2017. Analisa Kekuatan Impak Pada Penyambungan Pengelasan Smaw Material Assab 705 dengan Variasi Arus Pengelasan. 15, 58-63.

Kuntjojo. 2009. Metodologi Penelitian. Kediri

Suarsana. 2017. Ilmu Material Teknik. Program Studi Teknik Mesin Fakultas Teknik Universitas Udayana

Sugiyono. 2015. Metode Penelitian Kualitatif, Kuantitaif, dan R\&D. Bandung: Alfabeta

Wiryosumarto, H, \& Okumura, T . 2004. Teknologi Pengelasan Logam (Cetakan 9). Jakarta: PT Pradnya Paramita 